\title{
自律移動ロボットとタッチパネルを利用した調理作業支援システム*
}

$\begin{array}{lllll}\text { 福 } ⿴ 囗 十 ~ & \text { 司*1, 中 } & \text { 内 } & \text { 靖*2 } \\ \text { 野 } & \text { 口 勝 } & \text { 則*3, 松 原 } & \text { 隆*4 }\end{array}$

\section{Cooking Procedure Support System by Using Autonomous Mobile Robot and Touch Panel}

\author{
Tsukasa FUKUDA, Yasushi NAKAUCHI*5, \\ Katsunori NOGUCHI and Takashi MATSUBARA
}

\begin{abstract}
${ }^{* 5}$ Department of Intelligent Interaction Technologies, Graduate School of Systems and Information Engineering, University of Tsukuba, 1-1-1 Tennodai, Tsukuba-shi, Ibaraki, 300-8573 Japan

In this paper, we propose human activity recognition system, which infers the next human action by taking account of the past human behaviors observed so far. We also developed cooking support system by using an LCD touch panel on the kitchen counter and a mobile robot on the floor, which suggest what the human should do next by voice and gestures. Experimental resuls confirmed the feasibility of the inference system and the quality of support.
\end{abstract}

Key Words : Human Interface, Pattern Recognition, Robot, Intelligent Environments, Data Mining

\section{1.はじめに}

近年, 情報家電をはじめとして, 人を取り巻く様々 な機器がコンピュータ化されるとともに, ネットワー クに接続されつつある. 人を取り巻く多数のセンサを 用いて，琹境内で活動する人の行動状態を把握し，そ の情報を萫㯖することができれば，人の活㲜状況に応 じた，より高度なサービスを提供できるものと考えら れる.このようなアイデアは, Weiserによって提案 されたユビキタス・コンピューティング ${ }^{(14)}$ を起源と している. その後, Intelligent Space ${ }^{(4)}$, EasyLiving ${ }^{(2)}$,

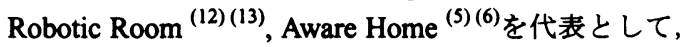
様々なシステムの開発ならびに研究が推進されてきて いる.

これらの研究では，砵境に遍在するセンサを用いて， いかに人の行動を認識し，人の行動支援を行うかが課 題となる. EasyLiving ではコンピュータのディスプレ イを, Intelligent Space では移動ロボットを，移動す る人の位膡を天井に配圈したカメラによって取得し， 人に追従（ローミング）させるサービスを実現してい る. Robotic Room では，人が指し示す物体を画像処 理によって特定し，マニピュレータにより手渡しをす

* 原稿受付 2005 年 2 月 24 日.

*1 筑波大学工学システム学類 (300-8573 つくば市天王台 1 1-1).

*2 正員、筑波大学大学院システム情報工学研究科

*3 海上自衛陏世保造修補給所( 857-0063 佐世保市立神町 無番地)

*4 防衛大学校情報工学科（亚239-8686 横須賀市走水 1-10-20）.

E mail : nakauchi (a iit.tsukuba.ac.jp
るサービスを実現している. Aware Homeでは, ベイ ズ分別器に基づく学習機能を利用することにより, 人 の行動状況を把握するシステムを開発している(5)(6). また，我々もこれまでに，ID4に基づく学習機能を利 用することにより，人の行動状況を把握するシステム として Vivid Room を開発している ${ }^{(8) \sim(10)}$.

上記に述べた研究では, 人が現在, 何をしているか の行動状態を把握している．例えば，玄関から入った 人が冷蔵庫をあけてからテーブルに着いたことによ り，その人が食事中であることを認識するといった具 合である.ここで,「風呂の用意をしましょうか?」と いった気の利いたサービスを行おうとすると，その人 が食事中であるという状況を認識するだけでは十分で はない，その人がいつも食事の後に風呂に入っている といった，過去に観測された時系列的な行動パターン を元に，その人が次にとるであろう行動を予測する必 要がある.

そこで本研究では，過去に観測された人の一連の行 動列を行動パターンとしたデータベースをもとに，現 在覒測されている人の行動パターンより，その人が次 に行うであろう行動を予測するデータマイニングの手 法を提案する. また，オフィスならびに家庭を想定し， マグカップ, インスタントコーヒー，スプーンなど環 境内に存在する物品に, 近年普及化が進められつつあ るICタグを装着することにより，環境内で活動する 人の行動を把握ならびに予測するシステムを構築する. 
さらに，認識された行動状況を元に，その人が次に 行うべき行動を音声ならびにジェスチャにより指示す る自律移動ロボット，ならびに，キッチンカウンター 上に設置したタッチパネルを利用して，調理のレシピ および調理手順を調理者の作業進捗状況に応じて表示 する情報呈示装置を開発する. そして, 開発した調理 支援システムの有用性について, 被䤅者を用いて検証 する.

\section{2. システム設㖕}

$2 \cdot 1$ 人の行動予測 観測可能な $\boldsymbol{n}$ 種類の行助の 集合を $A=\left\{a_{1}, a_{2}, \ldots, a_{n}\right\}$ とする. また, 任意の長さ の時系列的な行動の並びを行䌾パターン $p_{i}$ とし，人 の過去における行動パターン $m$ 個からなる行動パター ンの集合（データベース）を $P=\left\{p_{1}, p_{2}, \ldots, p_{m}\right\}$ と表 すこととする．例えば, インスタントコーヒーを作る 行動パターン $p_{i}$ は $\{$ コップを取り出す, コーヒーを 取り出す，砂糖を取り出す，ポットを手に取る,,,\}と いった行動列となる.

ここで，現在までに観測された，あるユーザの 行動パターンが $p_{o}=\left\{a_{3}, a_{2}, a_{4}\right\}$ であり, $P$ の中に $p_{o}$ に部分的に合致する行動パターンとして $p_{i}=$ $\left\{\ldots, a_{3}, a_{2}, a_{4}, a_{6}, \ldots\right\}$ が存在した場合, 当該ユーザは次 に行動 $a_{6}$ を実施するであるうと予測することができ る.人の行動は，必ずしも全てが手順どおりに実行 されるわけではなく，行動途中で何らかのノイズ（間 違った行動あるいは，ある意図を持って実施される一 連の行動とは無関係な行動）が混入することがある. 例えば，物を使って作業するときに，間邅って違う物 を取ったりすることことなどが挙げられる. 人の行動 を予測するシステムを考案する際，そのようなノイズ が混入したときにでも，的確な予測ができることが望 まれる

通常, 人の次の行動を予測するには，その行動に対 する時系列的な情報があれば可能だが，時系列的情報 だけでは，ノイズが混入したとき予測が困難となる. もし，システムが時系列的情報だけでなく，過去にお いて観察された行動パターンの発生頻度をあわせて利 用すれば，より的確な行動予測が行えるものと考えら れる. 例えば, 人が他人の行動を観察して, 次に何を 行うかを予測するとき，その人が突然普段行わないこ とをすれば，間違いと気づくはずである.なぜならば, 「普段行う行動」は発生の頻度が高い行動であるから である。

2.2 ノイスに強い行娌予測の考室本研究では, ノイズに強い行動予測を実現するため，時系列情報と

$\begin{array}{llll}a_{4} / 1 & a_{4} / 1 & a_{6} / 1 & \\ a_{1} / 1 & a_{6} / 1 & & \\ a_{2} / 3 & a_{4} / 2 & a_{6} / 2 & \\ a_{2} / 3 & a_{5} / 1 & a_{6} / 1 & \\ a_{2} / 3 & a_{6} / 3 & & \\ a_{3} / 4 & a_{1} / 1 & a_{4} / 1 & a_{6} / 1 \\ a_{3} / 4 & a_{1} / 1 & a_{6} / 1 & \\ a_{3} / 4 & a_{2} / 3 & a_{4} / 2 & a_{6} / 2 \\ a_{3} / 4 & a_{2} / 3 & a_{5} / 1 & a_{6} / 1 \\ a_{3} / 4 & a_{2} / 3 & a_{6} / 3 & \\ a_{3} / 4 & a_{4} / 3 & a_{6} / 3 & \\ a_{3} / 4 & a_{5} / 1 & a_{6} / 1 & \\ a_{3} / 4 & a_{6} / 4 & & \\ a_{4} / 3 & a_{6} / 3 & & \\ a_{5} / 1 & a_{6} / 1 & & \\ a_{6} / 4 & & & \end{array}$

Fig. 1 Time series data generated by PrefixSpan.

頻度情報に基づいた統計的マッチングによる行動予測 の手法を提案する．まずはじめに，時系列パターンを 見つけ出す代表的なアルゴリズムについて説明する．

時系列パターンマイニングの代表的な手法として は, Agrawal らによって提案された Apriori アルゴ リズム (apriori algorithm) ${ }^{(1)}$ が存在する. Apriori ア ルゴリズムについて，例を用いて简単に説明する. 例えば, $p_{1}=\left\{a_{3}, a_{2}, a_{4}, a_{6}\right\}, p_{2}=\left\{a_{3}, a_{2}, a_{4}, a_{6}\right\}, p_{3}=$ $\left\{a_{3}, a_{2}, a_{5}, a_{6}\right\}, p_{4}=\left\{a_{3}, a_{1}, a_{4}, a_{6}\right\}$ の 4 つの時系列デ一 タが過去に観察されたとする. Apriori アルゴリズム は, これらの時系列データから、ユーザが与えた確信 度および頻度の闑値を満たす時系列およびその部分列 に対し，例えば, $「 a_{3}$ の後に $a_{6}$ が起こる」という規則 を見つけ出す。ここで言う確信度とは， $a_{3}$ の後に $a_{6}$ が 起こる割合である.このような「 $a_{3}$ の後に $a_{6}$ が起こ る」といった規則は，相関ルールと呼ばれる. Apriori アルゴリズムは, 時系列の要素数が増えるにしたがっ て，計算量が指数関数的に大きくなることが実験的に 知られている.つまり，時系列が非常に巨大でかつ㻋 な場合，非常に多くのパターンを生成しなければなら ず，非効率的であると考えられる。

そこで Pei らは, Apriori アルゴリズムとは異 なる多頻度パターンを抽出するアルゴリズム PrefixSpan を提案している ${ }^{(11)}$. PrefixSpan について 例を用いて簡単に説明する．例として先ほどと同 様に, $p_{1}=\left\{a_{3}, a_{2}, a_{4}, a_{6}\right\}, p_{2}=\left\{a_{3}, a_{2}, a_{4}, a_{6}\right\}, p_{3}=$ $\left\{a_{3}, a_{2}, a_{5}, a_{6}\right\}, p_{4}=\left\{a_{3}, a_{1}, a_{4}, a_{6}\right\}$ の 4 つの時系列に ついて考える. これらの時系列について, PrefixSpan で計算した結果を図 1 に示す。

PrefixSpan は，時系列データより，時系列を維持 しつつ部分列を生成する，また，生成された部分 列の各イベントについて，その発生頻度を求める。 図 1 では $p_{1} \sim p_{4}$ の 4 種類の行動パターンより，16 種類の部分列が生成されている。また，例えば 8 
行目の $\left\{a_{3} / 4, a_{2} / 3, a_{4} / 2, a_{6} / 2\right\}$ は, $a_{3}$ のイベントが 単独で発生する頻度は 4 であることを表しており, $\left\{a_{3}, a_{2}, a_{4}, a_{6}\right\}$ の 4 つの行動が続けて発生する颊度は 2 であることを表している. このアルゴリズムは，実行 速度や，実装のしやすさの点で前述の Apriori アルゴ リズムより優れている.そこで本研究では, PrefixSpan を用いて, 人の行功予測に必要となる時系列的情報お よび頻度情報を取得することとする.

2.3 行娌パターンに基づいた人の行隹予测アルゴ リスム本研究で提案する行動予测アルゴリズムを 説明する．はじめに，使用する言葉を定義する.

時々刻々，センサによって取得される行動を入カイ ベント $w_{i}$ と定義する. 過去 $W$ 個に渡る入カイベント $\left\{w_{1}, \cdots, w_{W}\right\}$ による時系列データを幅 $W$ のウィンド ウと定義する.

入カデータをPrefixSpanによって抽出された時系 列データにマッチングさせるとき, マッチングはウィ ンドウ単位で行われる. 例えば, $W=5$ において入 カデータと一致する時系列データが存在しなければ, $W=4,3,2$ とウィンドウ幅を狭めて, マッチングを 行う. また, $W$ の最小值を $W_{\text {min }}$ と定義し, $W_{\min }$ 末満 の短い入カイベント列とのマッチングを行わないよう にし，不正確な予測を行わないよう工夫する．このよ うな可変幅のウィンドウを用いることにより, ウィン ドウ内にノイズを含む場合でも，それを取り除いた状 態でのマッチングを実現する.

時系列データに照らし合わせ，現在のウィンドウ中 の入カイベントの次に発生するであろう, 確率が最も 高い行動を予測イベントと定義する. 現在の状況に照 らし合わせ, 予測イベントが次の行動として生起する 確率を発生類度 (certainty) と定義し, 対応する時系列 データにおける予測イベントの頻度 $\left(O_{i a}\right)$ をその前件 となる一連の行動列の頻度 $\left(O_{p a}\right)$ で割ったものとして 表す（式 1）。

$$
\text { certainty }=\frac{O_{i a}}{O_{p a}},(0 \leq \text { certaint } y \leq 1)
$$

出力は EOS(End of Sequence), 予測イベント名: 発生 顂度, NULLの 3 種類とする. EOS は, 現在のイベン トが一連の行動の最後のイベントとなっている場合で あり，予測イベントが時系列データに存在しないとき に出力される. 予測イベントが求まった場合は, 予測 イベント名に併せて発生頻度が出力される. ウィンド ウ幅を $W_{\text {min }}$ まで狭めても, マッチングする時系列が 見つからないときに NULLが出力される.

以下にPrefixSpanにより得られる時系列データよ り，予測イベントを求めるアルゴリズムを説明する.
まず, $W=5$ (イベント) のウィンドウを作成し, 中 身を NULL で初期化する（手順 1）。次に，新たに観 測される入力イベントを $w_{W}$ とした, 過去 $W$ 個に渡 る入カイベントからなるウィンドウを作成する（手順 2) . そして, 時系列データの頭から $W$ 個のイベント とウィンドウとのマッチングをとり, マッチングする 時系列データが存在した場合, マッチングする時系列 データの数を求める（手順 3).

手順 3 において，マッチングする時系列データが 1 つの場合, 予測イベント $(W+1$ 番目のイベント)とそ の発生頻度 $=($ 予測イベントの発生頻度 $/ W$ 番目のイベ ントの発生頻度) を出力する. ここで, $W+1$ 番目の イベントが存在しない場合, EOS を出力する（手順 4）. また, マッチングする時系列データが複数の場 合, マッチングする時系列データのうち, 系列長が最 長のものを選択する（手順 5).

手順 5 において，選択されたものが 1 つの場合，手 順 4 の作業を実施する（図 2 参照）。選択されたもの が複数の場合， $W+1, W+2,$, , と参照するイベントを 遡り，発生頉度の多いものが含まれる時系列データを 選択する（手順 6)。選択された時系列データが $1 つ$ の場合は, 手順 4 の作業を実施する. また, 選択され た時系列データが複数の場合, 参照するイベントがな くなるまで, この作業を繰り返す。参照するイベント がなくなったら，選択された全ての時系列データにつ いて，手順 4 の作業を実施する.

また, 手順 3 において, マッチングする時系列デー タが存在しない場合, $W=W-1$ とし, 元のウィンド ウ内のイベント系列を維持した状態で, 複数のウィン ドウを用意して（手順 7)，手順 3 を実施する（図 3 参照 ${ }^{1}$ ）。ここで, $W<W_{\text {min }}$ となった場合 NULLを出 力する. 以上に述べた手順を表 1 に示す.

\section{4 人の行勗支援人が何らかの行動をしてい} るとき, システムが次の行動を予測し，その予測結果 に応じたリコメンドを示唆することができれば, 非常 に有益であると考えられる. その際, 人の行動を妨げ ることのないように支援することが重要と考える. そ こで本研究では, 人の行動過程に合った, 的確なリコ メンドを音声と画像表示によって行うシステムを開発

\footnotetext{
1図 3 には，ウィンドウ幅 5 の観測データが示されている.この 例では，ウィンドウ中の镜測データの 3 番目にノイズデータがあり， PrefixSpanより作成した時系列データとはマッチングするものを見 つけることができない：このような場合，ウィンドウ幅を 5 から 4 へと减らす. 元のウィンドウの時系列を維持した状態で, 1 筫所を 取り除く組み合わせにより，新たに 5 種類のウィンドウを作成し， 再びマッチングを行う. 図3では, 新たに作成されたウィンドウの うち, 上から 3 番目のものはノイズが除去されたものとなってお り，図2に示す方法と同様にマッチングを行うことにより, ウィン ドウ幅 4 にて，マッチングするものを見つけることが可能となる.
} 
Table 1 The procedure of matching algorithm.

\begin{tabular}{|c|c|}
\hline 手暊 & 実施内容 \\
\hline 1 & $\begin{array}{l}W=5 \text { とし, 偪 } W \text { のウィンドウ }\left\{w_{1}, w_{2}, w_{3}, w_{4}, w_{5}\right\} \text { を作成し中身を NULL } \\
\text { で初期化する. }\end{array}$ \\
\hline 2 & 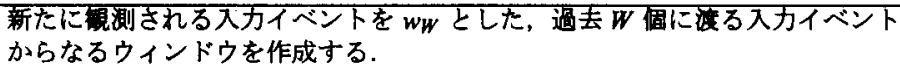 \\
\hline 3 & $\begin{array}{l}\text { 時系列データの頭からW } W \text { 個のイベントとウィンドウとのマッチンクをとる. } \\
\text { マッチングする時系列データが } 1 \text { つの堨合 } \Rightarrow \text { 手順 } 4 \text { に } \\
\text { マッチングする時系列データがー䙦数の堨合 } \Rightarrow \text { 手順 } 5 \text { に } \\
\text { マッチングする時系列データが存在しない䭪合 } \Rightarrow \text { 手順 } 7 \text { に }\end{array}$ \\
\hline 4 & 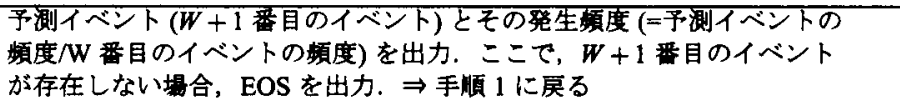 \\
\hline 5 & 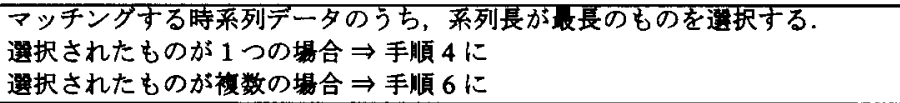 \\
\hline 6 & 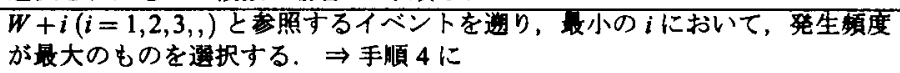 \\
\hline 7 & 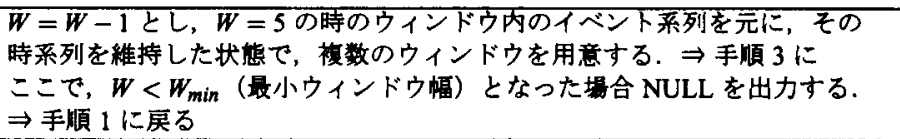 \\
\hline
\end{tabular}

Time Series Actions Window Width: $W=5$

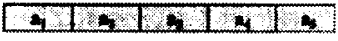

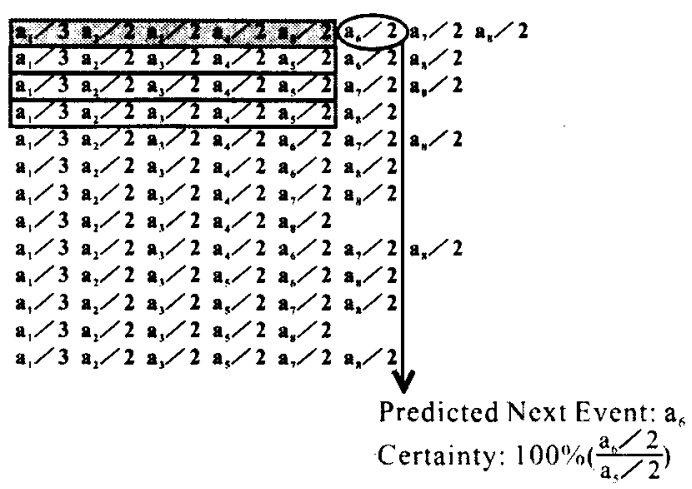

Fig. 2 Matching algorithm.

した.

本研究では，人に不快感を与えるリコメンドを減ら すために，予測した行動における発生頻度（式 1）に 閭値を設定し，闌値以下の予測行動については発話し ないようにした，閶値を設定するために，実際に10人 の被験者を用いて実呀を行い各リコメンドについて， コメントを述べさせたところ，被睮者に不快感を与え たリコメンドは，発生頻度が 0.55 未満に集中してい ることが分かった. そこで，予測した行動における発 生頻度が 0.55 に满たないものについては、リコメン ドを実施しないようにした。

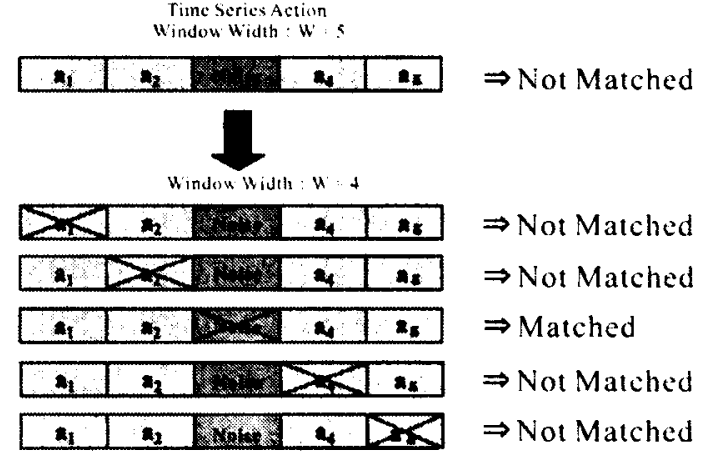

Fig. 3 Reduction of window size.

\section{3. 实葓}

3.1 IC タグシステム本研究では，FEIG ELCTRONIC 社製スマートタグシステムを利用し，家 庭内に存在する物品（マグカップ、インスタントコー ヒー, コップ, ティーパック, クリーム, スプーン, 敕

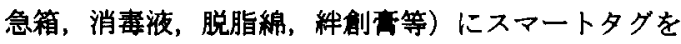
装着し，物品の取出し，格納等の情報をタダ情報とし て獾得できるようにした（因 4 参照）、スマートタグ はICチップと，コイルを含んだ繸 $2 \mathrm{~cm}$, 横 $4 \mathrm{~cm}$ ほど の IC タダで, フラット型のアンテナの約 $15 \mathrm{~cm}$ 以内 にかざすと、アンテナはスマートタグの ID 情報を取 得することができる．また，スマートタグからのID 情報は全てスマートタグシステムおよひ， RS-232C を 経てコンピュータに伝送される (図 5 参照). なお，本 来であれば物品を格納する全ての棚板にアンテナを仕 込むべきであるが，実装を简便化するため、テーブル 


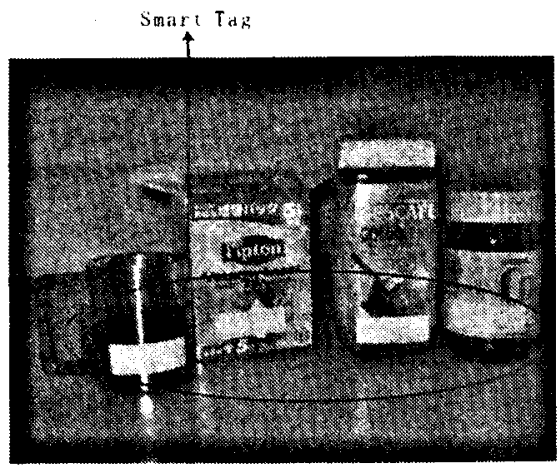

Fig. 4 Items labeled by IC tags.

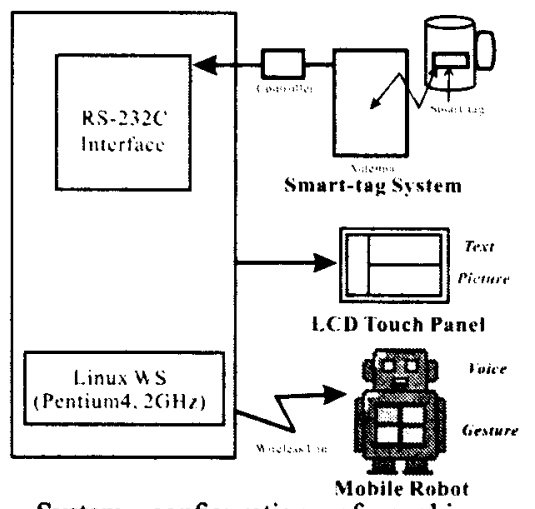

Fig. 5 System configuration of cooking support system.

トップ (キッチンカウンター) の上に 1 台のアンテナ を目き，個ヶの物品について，初めてスキャンされた 場合に取り出され，二度目にスキャンされた場合に元 の位瞜に戻されたものと判断することにし、ユーザが 利用する㗫にはそのように数示を行った.

3.2 人の行助予济本研究ではPrefixSpanに用 いる学習データを取得するため，時系列パターンとし て「風邪薬を服用する」，「伤の手当てをする」，「コ一 ヒ一を飲む」、「紅茶を飲む」の 4 状侦を考え, 10 人の 被䀫者に 4 つの行的を数示して実施させた。

取得された学習データの例を図 6 に示す. 本研究で は，1つのイベントから多くの情報を引き出し，より 的確な行动認識を実現するため, 学習データ中の各イ ベントにおいて場所と的作（取出し，格納）の情報を 加えている. それにより，ひとつのイベント情報から より多くの情報を得ることが可能となる.ちなみに、a は食器棚，bは戸棚，cは救急箱を表し，また，0は取 出し，1 は格納を表す．例えば, Spoon-a0は，スプー ンを食器棚から取出すことを表す.これらの学習デー タは全て，ICタグの ID 情報ならびにアンテナの位目

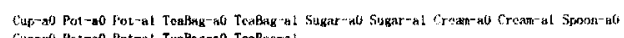

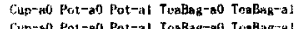

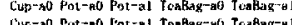

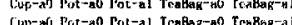

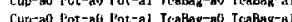

cup a

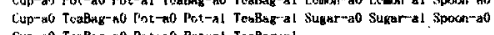

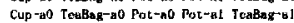

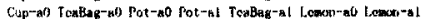

Fig. 6 Example of learning data.

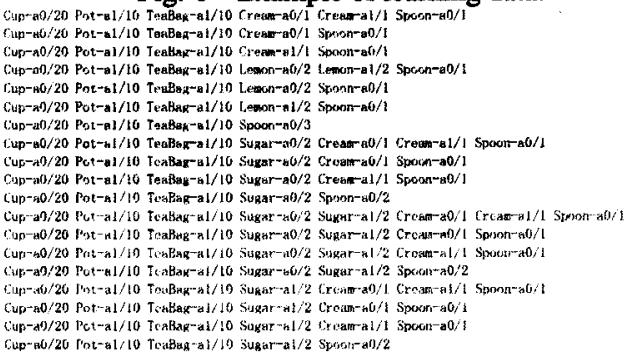

Fig. 7 Example of time series data generated by PrefixSpan.

情報として取得可能なため，被験者が作業を実施する ことにより，自動的に取得される.

次に,PrefixSpanによって抽出された時系列データ を図 7 に示す.ここに示されるデー夕は, 学習デー タにおける時系列パターンとその部分列から成る。” イベント名/数值”は，そのイベントの学習デ一タ全体 における頿度を表す，例えば，\{Cup-a0/20, Pot-a1/10， TeaBag-a1/10, Spoon-a0/3\} という時系列パターンか らは, Cup-a0 単独の発生瀕度は, 学習データ全体に おいて 20 ということになる. また，\{Cup-a0, Pot-a1， TeaBag-a1, Spoon-a0\}といった,「マグカップを食器棚 から取り出してから，ポットを食器棚に入れ，ティー パックを食器棚に入れ，スプーンを食器棚から取り出 す」行動パターンが発生する頻度は 3 であるというこ とになる。

3.3 人の行哩支㩧我々はATRが開発した自律 移動ロボット，Robovie ${ }^{(3)}$ を使用し，3.2 における予測 結果に応じて，音声合成とジェスチャにより，人の行 動状況に忍じたリコメンドを行う自律移動ロボットを 開発した（図 8 参照）。予測結果である行動のラベル には，例えば Spoon- $a 0 / 3$ といった具合に，対象と する物体，その物体のあるべき場所あるいは格納場所 の情報が含まれている。ロボットはこの情報を元に， 例えば，被験者がコーヒーを取出したら「砂糖は食器 棚にあります.」，風邪薬を服用した後，風邪薬を救急 箱に格納したら「救急箱は戸棚にいれます」といった 合成音声とともに，対象物の格納埸所をジェスチャに より指し示し，ユーザの作業を支援する.

我々はまた，LCD タッチパネルをキッチンカウン 


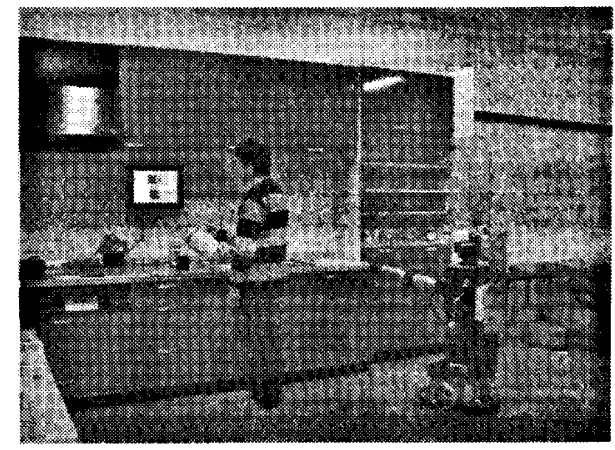

Fig. 8 Cooking support robot recommending a presumed next action to human by voice and gesture.

ターの壁に取り付け，自律移動ロボットと組み合わせ て使うことにより，人の調理状況に応じた支援を行う 調理支援システムを開発した。タッチパネル上には， 図 9 にあるように写真とともに調理レシピが表示さ れる．左側のフレームには番号付けされた全体の調理 手順が表示され，右側の二つのフレームには左側のフ レームの中から調理状況に応じて現在するべきこと， 次にするべきことの二つの手順についての詳細な情報 が表示される. 右側のフレームの上部分には, IC タグ により認識された行動についての情報が表示される。 例えば，コーヒーを作っている最中にポットを取出し たら，現在手に取っているポットを用いてお湯をカッ プに入れるという手順についての詳細な情報が上部分 に表示される。そして下部分には，左側のフレームの 調理レシピの順番に従った次の手順が表示される。 こ の時,システムが次の行動を予測した場合には，予測 された次の手順に関する情報が表示されるようになっ ている. 図 9 の例では, クリームを食器棚より取出す というのを次の行動として予測されており，クリーム の取扱い方についての情報が下部分に表示されている. これらの画面の切り替えは自動的に行われる.また， 使用者は左側に表示された全体の調理手順について， 任意の番号を指でタッチすることにより知りたい手順 についての情報を好きな時に見ることができるように なっている.

\section{4.实験および考原}

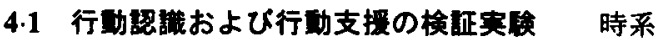
列パターンマッチングアルゴリズムによる行動認識の 妥当性と, 行動リコメンドシステムの有効性を評価す るために，学習データを取得した人とは異なる，10名

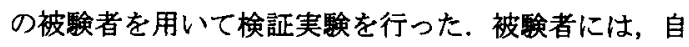

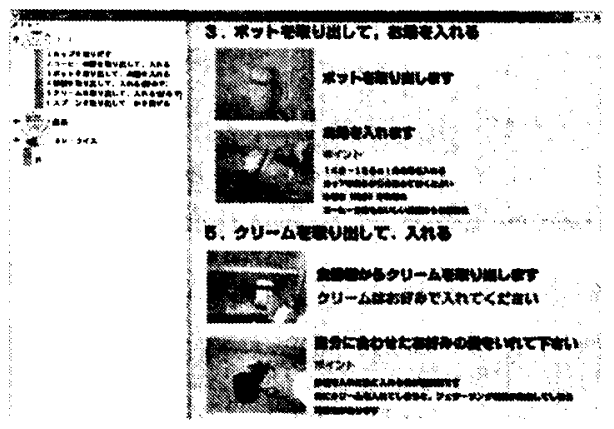

Fig. 9 Recipe shown on LCD.

Table 2 Phrases used for evaluation.

\begin{tabular}{|c|l|}
\hline Score & Phrase \\
\hline \hline 1 & "Thank you." \\
\hline 0 & (silent/ignore) \\
\hline-1 & "No thanks." \\
\hline
\end{tabular}

律移動ロボットが音声ならびにジェスチャにより支援 を行う度に，支援の妥当性について声を発してもらう ように数示した. 発声のパターンは表 2 に示す三種類 とし、それらはー1〜1の評価值として対応付けした. 実験の样子はビデオテープに収録し，自律移動ロボッ トが支援を行うたびに，被検者に発話を開き取り評価 值としてカウントした.

4.1.1 紧ータスク落行時の評洒 まずはじめに， 3.2 に示した「風邪薬を服用する」，「伤の手当てをす る」,「コーヒーを飲む」,「紅茶を飲む」の四種類の夕 スクそれぞれについて，適切な行功予測ならびに支援 が行われることを確認するために，被験者に四種類そ れぞれのタスクを実行させた. 被験者の発話による評 価值の平均を図 10 に示す. 全てのタスクにおいて評 価值の平均は 0.8 を上回っており，ほほ適切な行動予 測ならびにそれに基づく行朝支援が行われていること が確誌できた。

中でも「風邪㩰を服用する」タスクでは評価值が 高くなっているが, この結果を衰付けるコメントとし て、「風邪薬とコップは別々のところに囯いてあるため, どちらかを取り出すと，もう一方の物の格納場所を口 ボットが指し示して教えてくれることが㯖しかった.」 というものがあった. 本研究では音声だけでなく、口 ボットによる指差し的作を併用したが，実空間におけ る対象物の指示においてロボットの利用が有効であっ たと考えられる.

また，例えば，ストレートティを飲もうとしてレモ ンを入れることを示唆されたなど，被験者の啫好とは 異なる行動を指示された場合があったが、「レモンを入 


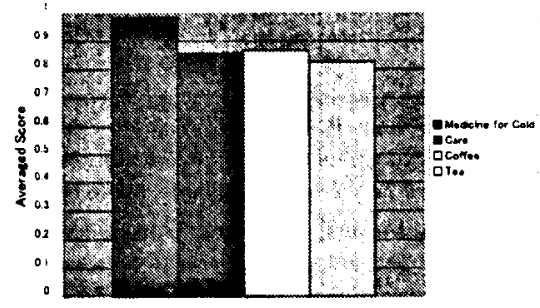

Fig. 10 Evaluation of adequacy in each task.

れてはという示唆自体は別におかしなものではなく， 別に気にならななかった.」というコメントを得た.こ れは，本システムが過去に锶察された典型的な行動パ ターンに基づく行動予測をしているためである．個人 の啸好を知らない人が，紅茶を飲む人に対してレモン を入れることを楽めるといった行功は日常の生活でも 見受けうることができ，本システムも同レベルでの対 人サービスを行うことができていると考えられる.

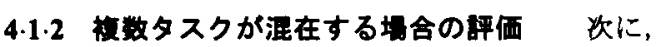
行的予測が困難（ノイズの混入事が高い）となる場合 において，適切な行功予测ならびに支援が行われるこ とを確認するために，2 人の被験者それぞれに別の夕 スクを同時に実行させて評価を行った，被殹者がタス クを実行する際には，互いの行動を交互に行ってもら うこととした．このため，2つの異なるコンテキスト に基づく行敉列が交互に锤测されることとなる.この ため,一方の被踾者にとっては，もう一方の被预者の 行功は「ある意図をもって春施される一連の行動とは 無関係な行轩」であり，ノイズとなる. 被監者の発話 による評価值の平均を図 11 に示す.

単一タスク遂行時に比べて，平均値は約 0.7 と多少 は下がっているが，それでも高い評価值を得られてい ると考える. 実験の様子を钼察したところ，一方の被 㲬者が何かを取り出したタイミングにおいて，そのタ スクに関する行動情報がウィンドウ内で支配的になる ため，その被倹者に対応した行功予測が適切に行われ ていた．また，ロボットによる支援についても，被験者 が対象物を取り出したタイミングで発話ならびにジェ スチャの呈示が行われるため，手を伸ばすなど、行動 を起こした被䀫者が自分に対しての支援であることが 自然と理解されていた。このことは、「自分に対して適 切なリコメンドがされていない場合があったが，それ はもう一方の作業者へのリコメンドであることが容易 に理解でき，別に不快には感じなかった.」とのコメ ントからも，確認することができる.

なお，本実験では種別の異なる2種類のタスクにお いて良好な結果が得られたが，タスクの種類が類似し

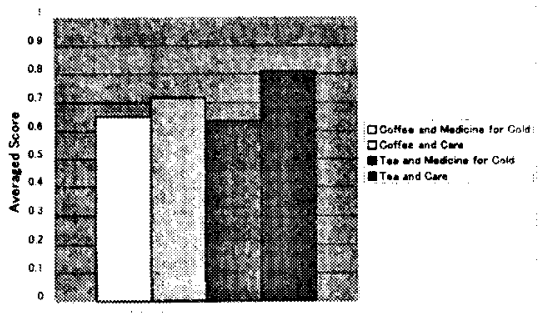

Fig. 11 Evaluation of adequacy when two tasks were observed mutually.

ている場合には適切なリコメンドを行うことが困難に なると考えられる、複数人が同時に作業を行うような 場合に対応するには，将来的には個人識別を行えるよ うにシステムを改善する必要があると考えられる.

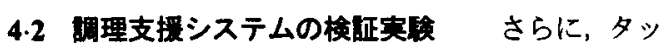
チパネルとロボットからなる，2 種類の支援方法の組 み合わせによる調理支援システムについての妥当性を 評価するために、コーヒーを作る場合について，3 種 の支援方法（(1) タッチパネルによる支援，(2）ロボッ トによる支援，(3）タッチパネルとロボットの両方に よる支援）における検証実験を行った１0名の被験者 には，調理作業終了後に（a）作業手順の分かりやす さ，(b) 物の位置の分かりやすさ，(c) レシピの進捗状 況の分かりやすさ, (d) 調理作業の楽しさ, の4 項目 について，-2〜2の評価值をつけてもらった. 図 12 に4 種の評価指標それぞれにおける 3 種の支援方法の 評価を示す.

実験結果より，タッチパネルによる支援では詳しい 手順内容を伝える, 調理作業の進渉状況を認識する, という2 項目についての評価が高いことが分かる.こ れは、タッチパネルは画像による視覚的な支援を行う のに適しているからであると考えられる. 一方, 口ボッ トによる支援では物品の格納場所を伝える, 調理作業 の楽しさを增加させる, という2 項目についての評価 が高いことが確認できる.これは，ロボットが空間的 な位膡情報を伝えるのに適しており，また，人と共同 して調理作業を行っているように感じられるからであ ると考えられる. 全ての項目において，どちらか片方 だけによる支援よりも，タッチパネルとロボットの両 方を併用した支援の方が評価が高くなっていることも 確認できる。

\section{5.おわりに}

本研究では, 過去に観測された人の一連の行動列を 行動パターンとしたデータベースをもとに，現在観測 


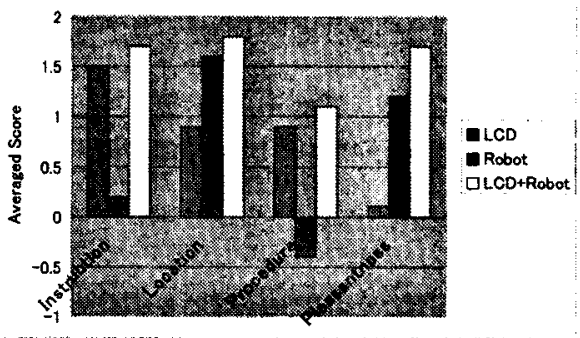

Fig. 12 Evaluation of the support by LCD and mobile robot.

されている人の行動パターンより，その人が次に行う であろう行動を予測するデータマイニングの手法を提 案した．また，オフィスならびに家庭を想定し，マグ カップ, インスタントコーヒー、スプーンなど襄境内 に存在する物品に, 近年普及化が進められつつある IC タグを装着することにより，環境内で活動する人の行 動を把捯ならびに予测するシステムを樓築し，認識さ れた行動状況を元に，その人が次に行うべき行動を音 声ならびにジェスチャにより指示する自律移動ロボッ トを開発した.さらに，被験者を用いた評価実験によ り，提案システムの有效性を検証し，二人のニーザが 同時に異なるタスクを実行するような場合においても， ノイズに頑強な適切な行功予測ならびに支援を行える ことを確認した．また，開発した自律移動ロボットと キッチンカウンターに取り付けた LCDタッチパネル を組み合わせて使うことにより，人の調理状況に忘じ た支援を行う調理支援システムを開発し，被蹹者を用 いた評価夷験により，その有効性を検証した。

今後, カメラやレーザーレンジファインダなど, 使 用するセンサ数を増やし, 認識可能な人の行動の種類 を増やす計画である．また，調理支援システムについ ても，本研究ではコーヒーを入れるなど比較的简単な 調理を対象としたが，今後はカレーライスの調理など， より襍雑な調理タスクを対象とし，支援可能なレシピ の種類を増やしていく計画である.

なお，現段階では学習デ一タの取得は，対象となる タスクごとにあらかじめ取得しておく必要がある．将 来的には，IC タグは現在の一次元バーコードに代わっ て普及し，家庭内にある様々な物品はICタグにラベ リングされているとともに，規格化された ID 情報に より，アンテナにかざされた際にそのものが何である かを一意に特定できるようになると考えている．その ため，将来的にはレシピ情報および対象タスクの学習 データをネットワーク上からダウンロードさせること により，様々なタスクに対応可能なシステムとして運
用が可能になると考えている.

\section{女 部}

(1) R. Agrawal and R. Strikant: Fast algorithms for mining association rules, Proc. of the 20th International Conference on Very Large Databases, pp.487-499, 1994.

(2) B.Brumitt, B.Meyers, J.Krumm, A.Kern and S.Shafer: EasyLiving: Technologies for Intelligent Environments, Proc. of International Symposium on Handheld and Ubiquitous Computing, pp.12-29, 2000.

(3) H. Ishiguro, T. Ono, M. Imai, T. Maeda, T. Kanda, and R. Nakatsu, "Robovie: A robot generates episode chains in our daily life", Proc. of Int. Symposium on Robotics, pp.1356-1361, 2001.

(4) J.Lee, N.Ando, H.Hashimoto: Design Policy for Intelligent Space, Proc. of IEEE International Conference on System. Man and Cybernetics (SMC'99), Oct., 12-15, 1999.

(5) D.J. Moore, I.A. Essa, and M.H. Hayes III:ObjectSpaces: Context Management for Human Activity Recognition, Geongia Institute of Technology, Graphics, Visualization and Usability Center, Technical Report \#GIT-GVU-9826, 1998.

(6) D.J. Moore, I.A. Essa, and M.H. Hayes III:Exploiting Human Actions and Object Context for Recognition Tasks, Proc. of The 7th IEEE International Conference on Computer Vision, pp.80-86, 1999.

(7) Yasushi Nakauchi, Tsukasa Fukuda, Katsunori Noguchi and Takashi Matsubara: Human Action Support and $\mathrm{Ma}$ in Intelligent Environments, Prc. of SICE System Integration Division Annual Conference(SI2004), pp 142-143, 2004.

(8) Yasushi Nakauchi, Katsunori Noguchi, Pongsak Somwong and Takashi Matsubara: Human Intention Detection and Activity Support System for Ubiquitous Sensor Room, Journal of Robotics and Mechatronics, Vol.16, No.5, pp545-551, 2004.

(9) Katsunori Noguchi, Pongsak SOMWONG, Takashi Matsubara, Yasushi Nakauchi and Eiichi KASHIWAGI: Human Activity Detection System in Sensor Embedded Room, Proc. of 2003 JSME Conference on Robotics and Mechatronics(ROBOMEC'03), No.1PI-3F-E7, 2003.

(10) Katsunori Noguchi, Pongsak SOMWONG, Takashi Matsubara and Yasushi Nakauchi: Human Activity Support System in Sensor Embedded Room, Proc. of SICE System Integration Division Annual Conference(SI2003), pp.193-194, 2003.

(11) J.Pei et al.: PrefixSpan: Mining Sequential Patterns Efficiently by Prefix-Projected Pattern Growth, Proc. of International Conference of Data Engineering, pp.215224, 2001.

(12) Tomomasa Sato: Networked Intelligent Machine to Support Daily Life - Trials of Robotic Room, TOSHIBA Review, Vol.56, No.9, pp.28-32, 2001.

(13) Tomomasa Sato, Taketoshi Mori and Tatsuya Harada: Intelligence of Robotic Room - Ubiquitous Intelligence -, Journal of the Robotics Society of Japan, Vol.20, No5, pp.482-486, 2002.

(14) M.Weiser: The Computing for the Twenty-First Century, Scientific American, pp.94-104, September, 1991. 